\title{
The Wilms' tumor 1 (WT1) gene (+KTS isoform) functions with a CTE to enhance translation from an unspliced RNA with a retained intron
}

\author{
Yeou-cherng Bor, ${ }^{1}$ Jennifer Swartz, ${ }_{1}^{1}$ Avril Morrison, ${ }^{2}$ David Rekosh, ${ }^{1}$ Michael Ladomery, ${ }^{2}$ \\ and Marie-Louise Hammarskjöld ${ }^{1,3}$ \\ ${ }^{1}$ Myles H. Thaler Center for AIDS and Human Retrovirus Research and Department of Microbiology, University of Virginia, \\ Charlottesville, Virginia 22908, USA; ${ }^{2}$ Centre for Research in Biomedicine, Bristol Genomics Research Institute, University \\ of the West of England, Bristol BS16 1QY, United Kingdom
}

The Wilms' tumor 1 (WT1) gene plays an important role in mammalian urogenital development, and dysregulation of this gene is observed in many human cancers. Alternative splicing of WT1 RNA leads to the expression of two major protein isoforms, WT1(+KTS) and WT1(-KTS). Whereas WT1(-KTS) acts as a transcriptional regulator, no clear function has been ascribed to WT1(+KTS), despite the fact that this protein is crucial for normal development. Here we show that WT1(+KTS) functions to enhance expression from RNA possessing a retained intron and containing either a cellular or viral constitutive transport element (CTE). WT1(+KTS) expression increases the levels of unspliced RNA containing a CTE and specifically promotes the association of this RNA with polyribosomes. These studies provide further support for links between different steps in RNA metabolism and for the existence of post-transcriptional operons.

[Keywords: WT1; Wilms' tumor; CTE; constitutive transport element; RNA export; post-transcriptional regulation; translational regulation]

Supplemental material is available at http://www.genesdev.org.

Received December 19, 2005; revised version accepted April 19, 2006.

The WT1 tumor suppressor gene was first identified and cloned based on a chromosome 11 deletion associated with WAGR syndrome (Wilms' tumor, aniridia, genitourinary malformations, and mental retardation) (Call et al. 1990; Gessler et al. 1990). WT1 encodes gene products that have been shown to play critical roles in the normal development of several organs in vertebrates, most notably the urogenital system (for review, see Discenza et al. 2004). Mutations in the WT1 gene have been detected in several human diseases including Wilms' tumors (nephroblastoma), Denys-Drash syndrome (typified by severe mesangial sclerosis), and Frasier syndrome (focal segmental glomerular sclerosis, pseudohermaphroditism, and gonadoblastoma). We have recently used siRNA to show that WT1 is required at specific stages of nephrogenesis in an ex vivo mouse kidney development system in which WT1 silencing is associated with a block in nephrogenesis, and abnormal levels of cell proliferation and apoptosis (Davies et al. 2004). In addition to its role

${ }^{3}$ Corresponding author.

E-MAIL mh7g@virginia.edu; FAX (434) 982-1590.

Article published online ahead of print. Article and publication date are online at http://www.genesdev.org/cgi/doi/10.1101/gad.1402306. in urogenital development, WT1 is also involved in hematopoiesis and is of great interest to clinicians due to its misexpression in acute myeloid leukemia (Rosenfeld et al. 2003).

The WT1 gene encodes four Krüppel-type $\mathrm{Cys}_{2}-\mathrm{His}_{2}$ zinc fingers, consistent with a function as a transcriptional regulator. WT1's zinc fingers place it in the early growth response (EGR) family of transcription factors, and several studies have documented that WT1 can function in this capacity, either as an activator, a repressor, or a coactivator of a variety of growth-associated genes (for review, see Scharnhorst et al. 2001). The WT1 gene consists of 10 exons and is alternatively spliced. Exon 5 can be skipped; its inclusion adds 17 amino acids in the central part of the protein. An alternative splice donor site at exon 9 inserts only three amino acids-lysine, threonine, and serine (KTS)-between the third and fourth zinc fingers (Haber et al. 1991; Gessler et al. 1992). A new class of mRNA transcripts has recently been described (AWT1), arising from the use of an alternative exon 1 present in intron 1. The use of this exon results in the use of an alternative, internal AUG start codon (Dallosso et al. 2004). In summary, alternative splicing, combined with upstream CUG alternative translation initiation 
codons and RNA editing, results in the potential expression of numerous WT1 isoforms. Of these isoforms, the most conserved are the ones arising from the $+/$-KTS alternative splicing (Kent et al. 1995).

Whereas WT1(-KTS) has the properties of a typical DNA-binding transcription factor (Rauscher et al. 1990; Bickmore et al. 1992), no clear role has been established for the WT1 $(+\mathrm{KTS})$ protein, which binds DNA with reduced affinity (Laity et al. 2000; Zhai et al. 2001). The + /-KTS isoform ratio is tightly regulated, and disruption of the ratio has been implicated in the pathogenesis of Frasier syndrome in humans and in mice (Barbaux et al. 1997; Klamt et al. 1998; Hammes et al. 2001). Interestingly, a recent study has further highlighted the importance of the WT1(+KTS) isoform, by demonstrating that it is required for normal development of the olfactory system (Wagner et al. 2005).

Several studies have suggested that WT1(+KTS) may function mainly at the post-transcriptional level. A potential connection between the +KTS isoforms and RNA processing was originally suggested by Larsson et al. (1995), who demonstrated a preferential localization of WT1(+KTS) in nuclear speckles. Treatment with RNase, but not DNase, altered WT1(+KTS) nuclear localization, and the protein coimmunoprecipitated with snRNPs. Later work showed that WT1(+KTS) specifically associates with U2AF65, a key splicing factor (Davies et al. 1998), and WTAP, a putative splicing factor. The Drosophila homolog of WTAP, female-lethal $(2) \mathrm{D}$, is involved in the alternative splicing sex determination pathway (Ortega et al. 2003). Furthermore, WT1 is present in poly $(\mathrm{A})^{+} \mathrm{RNPs}$ in expressing cell lines and fetal kidney extracts (Ladomery et al. 1999), and can shuttle between the nucleus and cytoplasm (Vajjhala et al. 2003). The WT1 zinc fingers have been shown to bind to RNA, both in vitro and in vivo, with zinc finger 1 being particularly important in RNA binding (Caricasole et al. 1996; Ladomery et al. 2003). Despite these numerous studies, a functional role for WT1(+KTS) in post-transcriptional gene regulation has not been established, and no definite in vivo RNA targets have been identified to date (Bardeesy and Pelletier 1998).

In previous studies, we have used HIV and other retroviral systems as models for elucidating mechanisms underlying the export and expression of mRNA possessing one or more retained introns. Retroviral RNAs contain special cis-acting elements that enable the export of viral RNA containing unspliced introns. In the absence of these elements, these RNAs are retained in the nucleus, where they are eventually degraded. The Rev response element (RRE) in HIV was the first such element to be identified. The RRE functions in conjunction with the HIV Rev protein (Pollard and Malim 1998).

Another specific viral element capable of facilitating the export of mRNAs with retained introns is derived from Mason-Pfizer Monkey Virus (MPMV), a type D retrovirus, and is known as the constitutive transport element (CTE) (for review, see Hammarskjöld 2001). This element is essential for the export of the genomic, unspliced RNA that is expressed in MPMV-infected cells.
The CTE has been shown to substitute for Rev and the RRE in export of HIV mRNA and to promote the export of cellular RNAs with retained introns (Bray et al. 1994; Ernst et al. 1997). In contrast to the HIV RRE, which functions in conjunction with the viral Rev protein, the CTE interacts only with host-cell factors. It has been shown that the CTE binds specifically to Tap (NXF1), believed to play a major role as a cellular mRNA export receptor (Gruter et al. 1998; Izaurralde 2002). Tap forms a heterodimer with the cellular NXT1 protein (Fribourg et al. 2001), and both Tap and NXT1 have been shown to be important for CTE function (Katahira et al. 1999; Braun et al. 2001; Guzik et al. 2001). Although Tap and NXT1 function in mRNA export pathways, we have recently demonstrated that these proteins also promote translation of CTE-mRNA in the cytoplasm, with Tap, but not NXT1, associating with polyribosomes (Jin et al. 2003).

The fact that host-cell proteins interact directly with the MPMV CTE to regulate post-transcriptional gene expression has led us to hypothesize the existence of cellular CTEs in the human transcriptome. These CTEs could function to enable cellular RNAs containing complete introns and other alternatively spliced RNAs to exit the nucleus and be translated in the cytoplasm. Although intron retention seems to be the least common form of alternative splicing in higher eukaryotes, several mammalian genes may be regulated in this way (Galante et al. 2004). To identify cellular CTEs, we developed an HIV vector-based CTE trap system (to be described in detail elsewhere). This system was specifically designed to enable the cloning of elements that can substitute for Rev/RRE to export unspliced HIV RNA to the cytoplasm.

Here we describe the identification of a cellular CTE that shows strong homology with an RNA that coimmunoprecipitated with epitope-tagged WT1(+KTS) protein. We demonstrate that this element can function as a CTE in HIV-based reporter assays. Furthermore, we demonstrate that expression mediated by this element is enhanced by WT1(+KTS). Our studies also show that the $\mathrm{WT} 1(+\mathrm{KTS})$ protein, in contrast to the WT1(-KTS) protein, is able to strongly enhance expression from reporter constructs containing the MPMV CTE. We show that the expression of WT1(+KTS) promotes the polysome association of CTE-containing RNA, indicating a role for this protein in translational regulation of target mRNAs.

These results clearly demonstrate for the first time that WT1(+KTS) can function to promote gene expression at the post-transcriptional level.

\section{Results}

The WT1(+KTS) protein enhances expression from unspliced RNA containing either a cellular or viral CTE

In the course of selecting potential constitutive transport elements from a COS cell cDNA library using an HIV vector trap system, we isolated a 594-nucleotide (nt) element (5A1) (Y.-c. Bor, D. Rekosh, and M.L. Hammar- 
skjöld, unpubl.). A portion of this element is identical to an RNA that was previously found in a protocol aimed at identifying genes regulated by the WT1 protein at the post-transcriptional level (M. Ladomery and N. Hastie, unpubl.). This RNA, named non-protein-coding T12 mRNA (GenBank accession no. 4375837), was isolated in a coimmunoprecipitation with epitope-tagged $\mathrm{WT} 1(+\mathrm{KTS})$ protein expressed in COS cells. As can be seen in Figure 1A, the 234-nt T12 mRNA shows perfect homology with the 5A1 CTE in a 208-nt stretch at the $3^{\prime}$ end of the $5 \mathrm{Al}$ sequence.

Since WT1(+KTS) has been proposed to function in post-transcriptional regulation, we decided to test whether expression of WT1(+KTS) in transfected cells had any effect on expression from reporter constructs containing either the $5 \mathrm{~A} 1$ sequence or the well characterized CTE from MPMV. 293T cells were chosen for these experiments, since it has been well established that these cells do not express detectable amounts of WT1 RNA or proteins (Thäte et al. 1998; Lee and Pel- letier 2001; Vajihala et al. 2003; Rae et al. 2004). Thus, these cells provide an excellent "complementation" system for analysis of WT1 effects. In addition, we have previously demonstrated that expression of Sam68 and Tap/NXT can enhance expression from CTE-containing RNAs in these cells (Coyle et al. 2003; Jin et al. 2003).

For these experiments we utilized a reporter assay based on the HIV-derived plasmid pCMVGagPol. A diagram of the important features of this plasmid is shown in Figure 1B. Expression of GagPol proteins from this plasmid requires export and translation of an unspliced RNA that retains a complete intron. This only takes place if the unspliced RNA contains a cis-acting RNA element that can overcome a cellular restriction that normally prevents its export and expression. Expression of GagPol proteins from the reporter construct leads to expression and secretion of particles that contain HIV p24, which can be measured using a specific ELISA. As a control, cells are also transfected with a CMV vector expressing secreted alkaline phosphatase (SEAP;

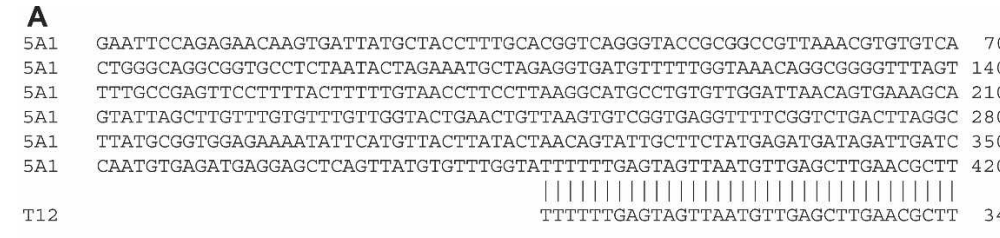
5A1 TCTTAATTGATGGCTGCTTTTGGGCCAACTATGGTGGTTGTGGTTTTTACTCTCTATGTAAGGTTTTTTC 490

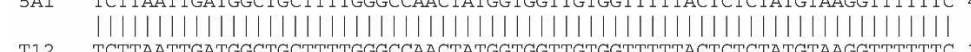

в

CTAGTGTCCAAAGAGCTGTCCCTCTTTGGACTAACAATTGAGTTTACAAGGGATTAAGTGGTTCTGTAG 560

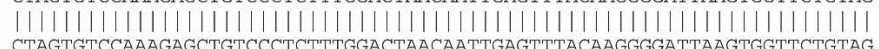
CTAGTGTCCAAAGAGCTGTCCCTCTTTGGACTAACAATTGAGTTACAAGGGGATTAAGTGGTTCTGTAG 174

GTAAGCTCAAGGTTGAACTAAGATTCTATCTTGG

|||||||||||||||||||||||||||||||||||||

GTAAGCTCAAGGTTGAACTAAGATTCTATCTTGGATAACCAGCTATCATCAGGCTCGGTA
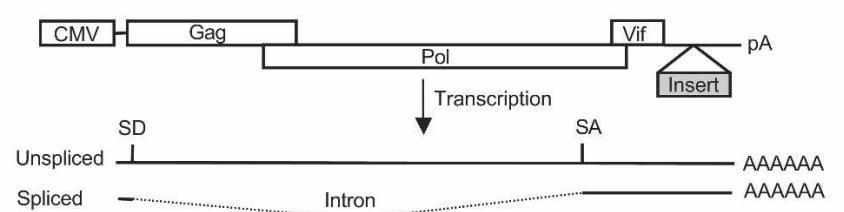

C
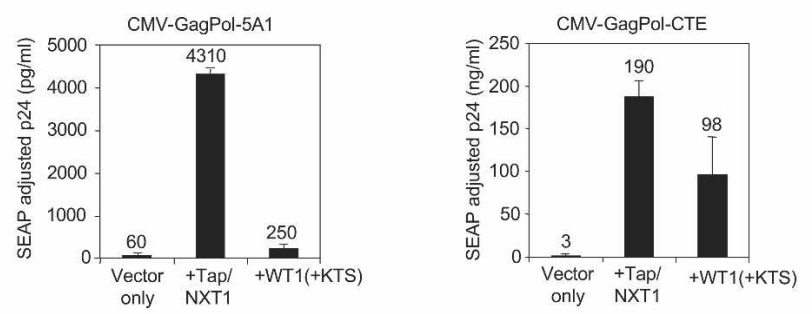

D
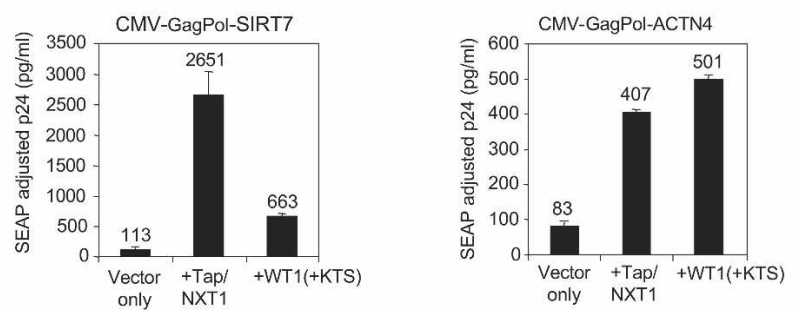

Figure 1. (A) Nucleotide sequence alignment of a cellular element, 5A1, with the non-protein-coding T12 mRNA sequence. Identical nucleotides are indicated by vertical lines. (B) Schematic drawing of reporter constructs used in this study. The reporter plasmids contain the HIV-1 gagpol coding sequence with expression driven by the CMV promoter. The resulting unspliced transcript, containing a complete intron, is retained in the nucleus without the presence of a CTE. In the presence of a CTE, the unspliced mRNA is exported to the cytoplasm, allowing the expression of HIV p24 from the gag gene. (SD) Splice donor; (SA) splice acceptor; (pA) polyadenylation signal. The dotted line below the spliced message depicts the removed intron. $(C)$ Expression of p24 from pCMVGagPol-5A1 or pCMVGagPolCTE is enhanced by cotransfection of plasmids expressing Tap/NXT1 or WT1(+KTS). 293T cells $\left(3 \times 10^{6}\right.$ cells in a $10-\mathrm{cm}$ culture dish $)$ were transfected with $15 \mu \mathrm{g}$ of pCMVGagPol-5A1 or $5 \mu \mathrm{g}$ of pCMVGagPol-CTE plasmids and $0.25 \mu \mathrm{g}$ of pCMVSEAP alone or together with $2 \mu \mathrm{g}$ of pCMVTap and $1 \mu \mathrm{g}$ of pCDNA3FLAGNXT1 or $5 \mu \mathrm{g}$ of WT1(+KTS) expression vectors. At $72 \mathrm{~h}$ posttransfection, supernatants were collected and analyzed for p24 levels and SEAP activity. The p24 values were normalized to SEAP values that serve as a control for transfection efficiency. The values shown are averages of duplicate transfections. $(D)$ Expression of p24 from pCMVGagPol-SIRT7 or pCMVGagPol-ACTN4 is enhanced by cotransfection of plasmids expressing Tap/NXT1 or WT1(+KTS). Transfections were performed and analyzed as described in $C$. 
pHR1831) that is also secreted into the medium of the transfected cells. Since SEAP is expressed from a conventional spliced mRNA, normalization to SEAP values corrects for both transfection efficiency and generalized effects on "normal" mRNA metabolism. We have previously shown that insertion of the MPMV CTE into the pCMVGagPol plasmid enables efficient export and expression of unspliced RNA (Srinivasakumar et al. 1997; Coyle et al. 2003; Jin et al. 2003).

$293 \mathrm{~T}$ cells were transfected with the 5A1 or MPMV CTE-containing pCMVGagPol reporter plasmids alone or together with a construct expressing the WT1(+KTS) protein. In parallel, we transfected cells with plasmids expressing Tap and NXT1 (pHR2128 and pHR2283). We have shown previously that moderate overexpression of Tap/NXT1 is able to enhance expression from the pCMVGagPol-CTE plasmid in 293T cells /Guzik et al. 2001; Jin et al. 2003). Figure 1C demonstrates that both Tap/NXT1 and WT1(+KTS) were able to significantly enhance expression from the plasmid containing $5 \mathrm{~A} 1$ as well as the plasmid containing the MPMV CTE. (In this experiment, SEAP values did not vary by more than twofold.) Although much lower expression was obtained from the plasmid containing 5A1 (note the scale change), these experiments clearly support the notion that 5A1 constitutes a cellular equivalent of the CTE.

The HIV vector trap system that led to the identification of the 5A1 sequence also identified several other CTEs from additional cellular genes. Included among these are actinin4 (ACTN4) and SIRT7 (see Supplementary Table S1 for a description of these elements). ACTN4 is potentially particularly relevant to WT1 function, since experiments using a three-hybrid system have shown that mRNA from a related family member ACTN1 is a potential WT1-binding target (Morrison et al. 2006). ACTN1 and ACTN4 (non-muscle-specific $\alpha$-actinins) are closely related and coordinately expressed. Furthermore, ACTN4 is known to be important in kidney function, and mutations in this gene cause focal segmental glomerular sclerosis (FSGS) (Kaplan et al. 2000). FSGS, a disease which is part of the triad seen in Frasier syndrome patients, is caused by altered WT1 $1+\mathrm{KTS}) / \mathrm{WT} 1(-\mathrm{KTS})$ ratios (Barbaux et al. 1997; Hammes et al. 2001). The function of SIRT7 is less clear, but recently the gene has been identified to express an mRNA that retains an intron (Galante et al. 2004).

To test the effects of WT1(+KTS) expression on the CTEs from ACTN4 and SIRT7, we created pCMVGagPol reporter plasmids containing these elements and measured p24 expression as described above. The data (Fig. 1D) clearly demonstrate that WT1(+KTS) enhanced expression about sixfold from these plasmids. Thus, this protein is able to enhance the function of at least three different cellular CTEs.

The WT1(-KTS) protein inhibits WT1(+KTS) function in a dose-dependent manner

Since the viral CTE gave much higher p24 levels and is a well-characterized post-transcriptional element, we con- tinued by analyzing the function of the WT1 protein with the GagPol-MPMVCTE reporter construct. First, we wanted to determine whether the enhancement that we had observed was specific to WT1(+KTS). To this end, we performed experiments in which increasing amounts of plasmids expressing either WT1(+KTS) or (-KTS) proteins were cotransfected with pCMVGagPol-CTE (pHR1361) (Fig. 2A-C). We also performed similar experiments using a plasmid expressing the EGR1 protein (Fig. 2D). Like WT1, the EGR1 protein contains $\mathrm{Cys}_{2}-\mathrm{His}_{2}$ zinc fingers at the $\mathrm{C}$ terminus. Zinc fingers 2, 3, and 4 of WT1 exhibit $60 \%$ amino acid homology with three zinc fingers of EGR1 (Rauscher 1993). However, in contrast to the WT1 proteins, this protein does not show significant binding to RNA.

As can be seen in Figure 2, A and B, the WT1(+KTS) protein enhanced CTE function in a dose-dependent manner, confirming and extending the previous results. At the highest concentration of WT1 $(+\mathrm{KTS})$, there was an $\sim 45$-fold increase in normalized p24 values (Fig. 2B). In contrast, WT1(-KTS) gave only a minimal increase in p24 expression ( 2.5-fold). However, the small increase that was observed can be clearly seen to be dose-responsive (see data plotted on expanded scale in Fig. 2C) and is likely to be significant, since it was observed in repeated experiments (data not shown). In contrast, expression of EGR1 did not give any significant increase in p24 expression (Fig. 2D). Western blot analysis of the expressed

A

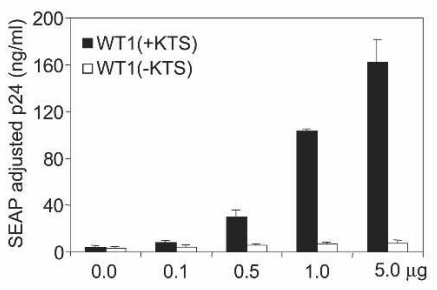

B
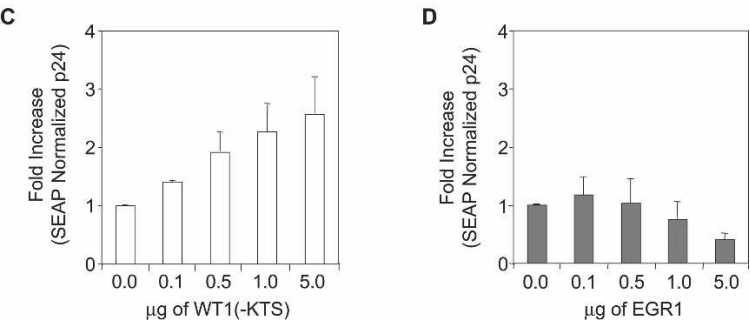

Figure 2. Effects of WT1 $1+\mathrm{KTS})$, WT1(-KTS), or EGR1 on p24 expression from pCMVGagPol-CTE reporter constructs in $293 \mathrm{~T}$ cells. Cells $\left(3 \times 10^{6}\right)$ were cotransfected with $5 \mu \mathrm{g}$ of pCMVGagPol-CTE, $0.25 \mu \mathrm{g}$ of pCMVSEAP, and increasing amounts of plasmids expressing either WT1(+KTS) or WT1(-KTS) $(A)$, or EGR1 proteins $(D) .(B, C)$ The same set of data shown in $A$ was plotted as "fold increase" on different scales. At $72 \mathrm{~h}$ post-transfection, supernatants were harvested and analyzed for p24 levels and SEAP activity. The p24 values shown have been normalized for SEAP activity. The data represent the average of two independent transfections. 
WT1(+KTS), WT1(-KTS), and EGR1 proteins showed that they were all expressed at similar levels (see Supplementary Fig. S1).

Since the WT1(+KTS) and WT1(-KTS) isoforms have been shown to form heterodimers, we next examined the effects of coexpression of these proteins on expression from the CTE. To do this, we performed two experiments in which a fixed amount of either the plasmid expressing the +KTS isoform or the plasmid expressing the -KTS isoform was cotransfected with increasing amounts of the other plasmid. The results of these experiments, shown in Figure 3, A and B, demonstrated that expression of WT1(-KTS) inhibited the effects of WT1(+KTS) in a dose-dependent manner. This indicates that expression of the WT1(-KTS) protein shows a trans dominant negative effect over the enhancement observed with the +KTS isoform. This observation may relate to the documented ability of WT1 to dimerize via the $\mathrm{N}$ terminus (Englert et al. 1995; Moffett et al. 1995; Reddy et al. 1995; Bruening et al. 1996).

Exon 5 sequences and the amino acid sequence of the three-amino-acid insertion in WT1(+KTS) are not essential for promotion of CTE function

Alternative splicing gives rise to several different isoforms of WT1. One of the alternative splicing events is
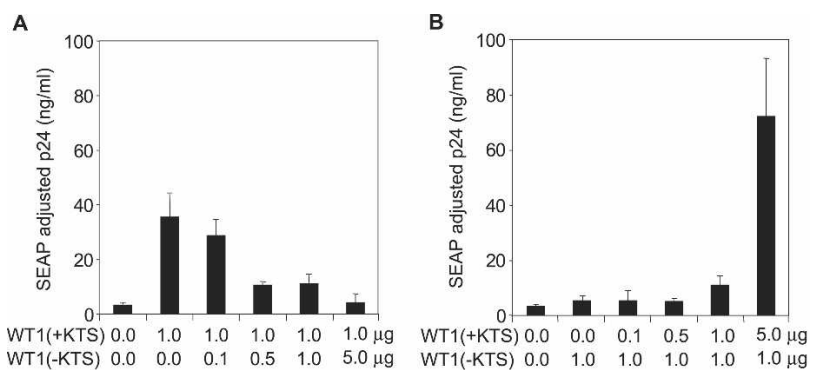

C
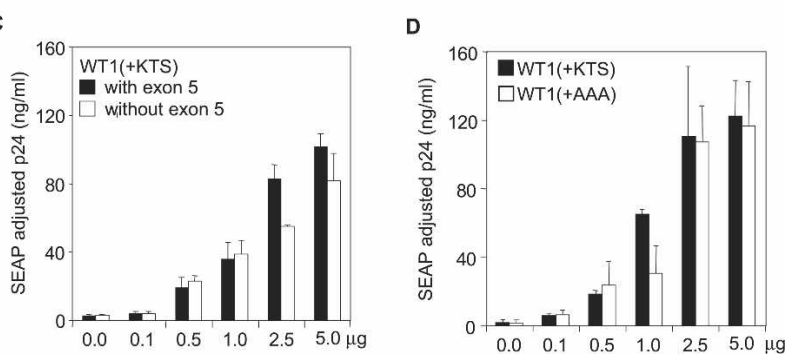

Figure 3. $(A, B)$ Overexpression of WT1(-KTS) inhibits the enhancement effects of WT1(+KTS) in transfected $293 \mathrm{~T}$ cells. Cells were cotransfected with $5 \mu \mathrm{g}$ of pCMVGagPol-CTE, 0.25 $\mu \mathrm{g}$ of pCMVSEAP, and increasing amounts of WT1(-KTS) $(A)$ or WT1 $1+$ KTS $)(B)$, while the amount of the plasmid expressing the other isoform was kept constant at $1 \mu \mathrm{g}$. $(C, D)$ Neither exon 5 nor the specific KTS amino acid sequence is important for the post-transcriptional function of WT1. Cells were cotransfected with $5 \mu \mathrm{g}$ of pCMVGagPol-CTE, $0.25 \mu \mathrm{g}$ of pCMVSEAP, and increasing amounts of WT1 constructs, as indicated in the figure. In all cases, the overall amount of plasmid transfected was kept constant using an empty vector. Transfections and analyses were performed as described in the legend for Figure 2. the skipping of exon 5 . The original experiments that we had performed (shown in Figs. 1C, 2A, 3A,B) all used WT1 proteins that included this exon. To investigate whether exon 5 was essential for enhancement of CTE function, we analyzed the effects of a WT1(+KTS) protein lacking this exon. The results of these experiments, shown in Figure 3C, clearly indicated that exon 5 is not essential for the observed effects.

We also constructed a plasmid expressing a variant of WT1, in which the sequence encoding the KTS motif was mutated to encode three alanines (AAA). Western blot analysis of the protein produced from this plasmid showed that it was expressed at levels similar to the other WT1 proteins (see Supplementary Fig. S1). Transfection experiments using this construct showed that this protein was able to enhance CTE function as well as the +KTS protein (Fig. 3D). This demonstrates that the amino acid sequence of the KTS insertion is not essential for CTE enhancement. This supports the notion that the KTS insertion merely serves to structurally disrupt the zinc finger region of the WT1 protein and that the specific amino acid sequence is not important (Davies et al. 2000; Laity et al. 2000).

\section{Both WT1(+KTS) and WT1(-KTS) increase total as} well as cytoplasmic levels of CTE-containing RNA

To analyze the potential mechanism for the observed effects of WT1 on CTE-mediated expression, we performed a Northern blot analysis of cytoplasmic as well as total RNA in cells transfected with WT1(+KTS)- or WT1(-KTS)-expressing plasmids. To control for fractionation, we also performed an analysis of cells transfected with the plasmid pCMVGagPol-RRE (pHR0354), in the absence or presence of Rev (pHR30). We and others have previously demonstrated that GagPol-RRE RNA is retained in the nucleus in the absence of Rev, but efficiently exported to the cytoplasm in its presence (Pollard and Malim 1998; Guzik et al. 2001; Coyle et al. 2003; Jin et al. 2003).

The results of this experiment are shown in Figure 4. The control experiment demonstrated that the levels of GagPol-RRE reporter RNA in the cytoplasm increased 24-fold in the presence of Rev, consistent with our previously published results (Guzik et al. 2001; Coyle et al. 2003; Jin et al. 2003). Total RNA levels were also increased, but only about fivefold. This has been observed previously, and is likely due to an increased stability of the RNA when it is exported to the cytoplasm and engaged by the translation machinery, compared with when it is retained in the nucleus.

In the transfections using the CTE construct, total RNA levels were increased about twofold in conjunction with WT1(-KTS), while the expression of WT1 $(+\mathrm{KTS})$ gave a fourfold increase. These results again most likely reflect a stabilization of the RNA, rather than a transcriptional effect, since the SEAP mRNA is expressed from the same promoter as the CTE RNA and the data are normalized using the SEAP mRNA. When cytoplasmic CTE-containing RNA was analyzed, WT1(-KTS) 


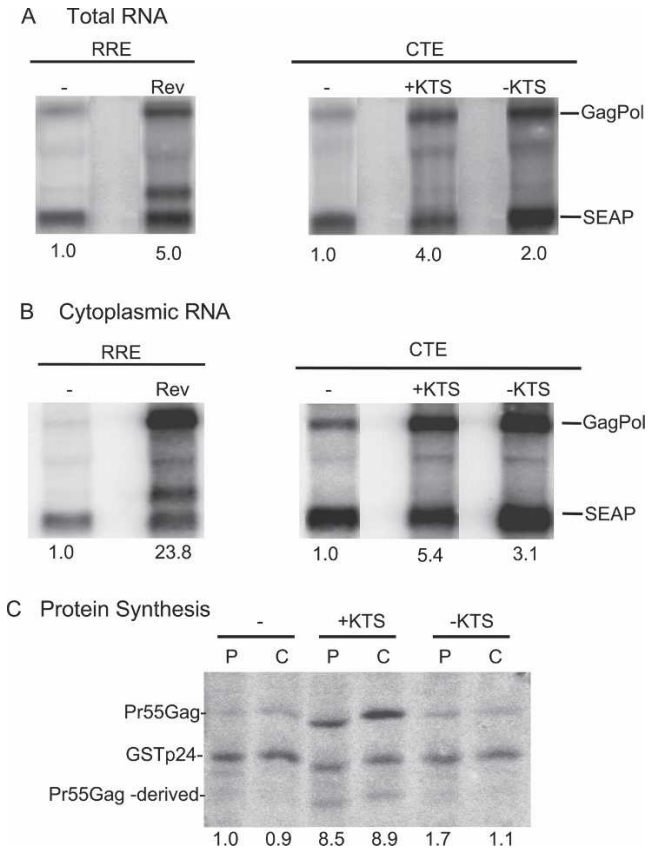

Figure 4. Northern blot analyses of total $(A)$ and cytoplasmic (B) mRNA, and protein synthesis levels $(C)$ of Pr55Gag in transfected cells. $(A, B) 293 \mathrm{~T}$ Cells $\left(1 \times 10^{7}\right.$ in $15-\mathrm{cm}$ culture dish $)$ were transfected with $15 \mu \mathrm{g}$ of pCMVGagPol-CTE and $5 \mu \mathrm{g}$ of pCMVSEAP in the absence or presence of $15 \mu \mathrm{g}$ of WT1(+KTS) or WT1(-KTS) plasmids. As a control, cells were also transfected with $15 \mu \mathrm{g}$ of pCMVGagPol-RRE and $5 \mu \mathrm{g}$ of pCMVSEAP in the presence or absence of $5 \mu \mathrm{g}$ of pCMVRev. Sixty-five hours post-transfection, total and cytoplasmic poly $(A)^{+}$mRNA was isolated from the transfected cells as described in Materials and Methods. The blot contains $5 \mu \mathrm{g}$ of poly $(A)^{+}$mRNA per lane and was hybridized with ${ }^{32} \mathrm{P}$-labeled GagPol and SEAP probes. The values shown in the panels marked RRE, on the left side of each figure, represent the fold difference in the levels of the GagPol RNA bands between transfections without and with Rev. The values under the CTE panels (the right side of the figure) represent the fold difference in the levels of the GagPol-CTE RNA in the presence of the indicated proteins compared with a transfection with pCMVGagPol-CTE alone. All values were normalized using the SEAP band. (C) Pulse-chase analysis of Pr55Gag protein expressed from pCMVGagPol-CTE $\left(\mathrm{myr}^{-} \mathrm{pro}^{-}\right)$in transfected $293 \mathrm{~T}$ cells. Cells $\left(3 \times 10^{6}\right)$ were transfected with $5 \mu \mathrm{g}$ of pCMVGagPolCTE $\left(\mathrm{myr}^{-}\right.$pro $\left.^{-}\right)$with or without $5 \mu \mathrm{g}$ of WT1(+KTS), or $5 \mu \mathrm{g}$ of WT1(-KTS). Thirty-six hours post-transfection, cells were pulsed with ${ }^{35} \mathrm{~S}$-translabel (methionine and cysteine) for $20 \mathrm{~min}$ and chased for $10 \mathrm{~h}$. Lysates were made, ${ }^{35}$ S-labeled GST-p24 was added as a recovery control, and immunoprecipitation was performed using an anti-p24 monoclonal antibody (183-H12-5C). The precipitates were analyzed on a $15 \%$ SDS-PAGE using a PhosphorImager. The lanes marked $\mathrm{P}$ contained the samples from the pulse and the lanes marked C contained the samples that were pulse-chased. The locations of the immunoprecipitated Pr55Gag band (and derivative) and the control GST-p24 protein are indicated. The relative normalized pixel intensity of the total Pr55Gag protein bands is shown under each lane. The data have been normalized using the intensity of the recovery control protein GST-p24 in each sample. was shown to increase the RNA levels about threefold, whereas a fivefold increase was observed in the presence of WT1(+KTS). These increases are only marginally different from what was observed in the total RNA preparation, suggesting that there was no significant specific increase in RNA export with either of these proteins. Clearly, the slightly increased RNA levels observed with both WT1 isoforms cannot account for the differential increase in p24 protein levels seen with WT1 $(+\mathrm{KTS})$ compared with WT1(-KTS). This becomes clear when the data for cytoplasmic RNA from this experiment are used to normalize the data shown in Figure 2. In that figure, transfection with $5 \mu \mathrm{g}$ of $\mathrm{WT} 1(+\mathrm{KTS})$ (the same amount used in this experiment) increased protein levels 42-fold, while transfection with WT1(-KTS) increased p24 values only 2.6 -fold. Thus, for WT1 $(+\mathrm{KTS})$ there is a $>7.7$-fold increase in protein levels (42/5.4) after normalization for RNA levels. On the other hand, for WT1(-KTS) the increase in RNA fully accounts for the increase in protein $(2.6 / 3.1)$.

\section{WT1(+KTS) increases the rate of synthesis of protein translated from GagPol-CTE RNA but WT1(-KTS) does not}

To determine if the difference in p24 accumulation levels between cells transfected with pCMVGagPol-CTE and WT1(+KTS) versus WT1(-KTS) was a direct result of an increased rate of protein synthesis, we decided to directly measure the relative rates. The pCMVGagPolCTE construct normally gives rise to polyproteins that are cleaved by the HIV protease and bud from transfected cells as virus-like particles. Because of this, it is difficult to directly visualize the primary translation product in transfected cells. This precludes a straightforward measurement of the rate of protein synthesis by examining the accumulating protein directly. To overcome this problem, we constructed a new plasmid, pCMVGagPol(myr pro $^{-}$-CTE (pHR2900). This plasmid has point mutations in the HIV protease active site that makes the protease inactive ( $\mathrm{pro}^{-}$) and in the $\mathrm{N}$ terminus of Gag that destroys the myristoylation signal $\left(\mathrm{myr}^{-}\right)$. Thus only nonmyristoylated Pr55Gag and Pr160GagPol precursors, and a minor derivative (p41), likely derived by the use of an internal initiation codon, are expected to be produced from these vectors (Smith et al. 1993). Since myristoylation is required for virus particle budding, these proteins would be expected to remain inside the transfected cell in an uncleaved form. This was verified by showing that no p24 was detected in the medium supernatant (data not shown) and that only uncleaved Pr55Gag proteins accumulated in the cytoplasm of transfected cells.

To directly analyze the rate of protein synthesis and/or stability of the synthesized proteins, we performed a pulse-chase experiment on cells transfected with the modified $\left(\mathrm{myr}^{-}, \mathrm{pro}^{-}\right)$CTE construct. At 36 h post-transfection, cells were pulsed with ${ }^{35} \mathrm{~S}$-translabel (methionine and cysteine) for $20 \mathrm{~min}$. The cells were then washed twice with PBS and harvested (pulse), or refed with growth medium containing excess cold amino acids 
and harvested $10 \mathrm{~h}$ later (chase). Cell lysates were subjected to immunoprecipitation using a mouse antiGag(p24) antibody and analyzed for Pr55Gag and p41 by SDS-PAGE and autoradiography. To compensate for potential differences in immunoprecipitation efficiency between samples, in vitro purified GST-p24 protein was added to the cell lysates before the immunoprecipitation. A second immunoprecipitation was also performed on the supernatants after the initial immunoprecipitation to judge the efficiency of the first precipitation. More than $95 \%$ of each protein was pulled down in the first precipitation (data not shown).

The results of this pulse-chase experiment are shown in Figure 4C. Only a very small amount of Pr55Gag was observed in the cells transfected with the GagPol-CTE plasmid alone. The amount of labeled protein did not decrease significantly after a $10-\mathrm{h}$ chase, indicating that the proteins produced were stable during this period. A significant increase in the intensity the of Pr55Gag band was observed in the presence of WT1(+KTS), but there was only a slight increase (if any) in the presence of WT1(-KTS). Again, the protein produced was stable during a 10-h chase period. When the data are normalized for cytoplasmic RNA levels, using the values shown in Figure $4 \mathrm{~B}$, the rate of Gag protein synthesis after transfection of WT1(+KTS) was twofold higher than the rate observed with no added WT1 protein. However, the rate differences between the transfections with WT1(+KTS) and WT1(-KTS) was about fivefold. This is the more important comparison, since the rate of synthesis might have been measured at a time when the effect of the WT1 proteins was not optimal. Thus, this experiment clearly indicated that WT1 $(+\mathrm{KTS})$ was able to specifically enhance translation from the GagPol-CTE RNA, as we previously observed for Tap/NXT1 (Jin et al. 2003).

\section{WT1(+KTS) increases association of CTE-containing RNA with polyribosomes}

To test whether expression of WT1(+KTS) resulted in an increased polyribosome association of the GagPol-CTE RNA, we made cytoplasmic extracts from cells that were transfected with either the reporter plasmids alone or the reporter plasmids and WT1 $(+\mathrm{KTS})$. The extracts were then subjected to sucrose gradient centrifugation and fractionated, and each fraction was analyzed on a Northern blot with the same probes that were used in the experiment shown in Figure 4. The results of this experiment are shown in Figure 5. For the cells transfected with the SEAP and GagPol-CTE plasmids alone, it is striking that the heavier polyribosomal fractions were largely devoid of GagPol-CTE RNA (Fig. 5A, left panels), although the SEAP mRNA was found throughout the gradient. Specifically, it was observed that a large percentage of the CTE-RNA localized to the fractions corresponding to monosomes and very small polyribosomes. This is likely to indicate poor initiation rates for the CTE-RNA and is consistent with our previous results demonstrating that GagPol-CTE RNA is poorly translated in 293T cells (Jin et al. 2003). Significantly,
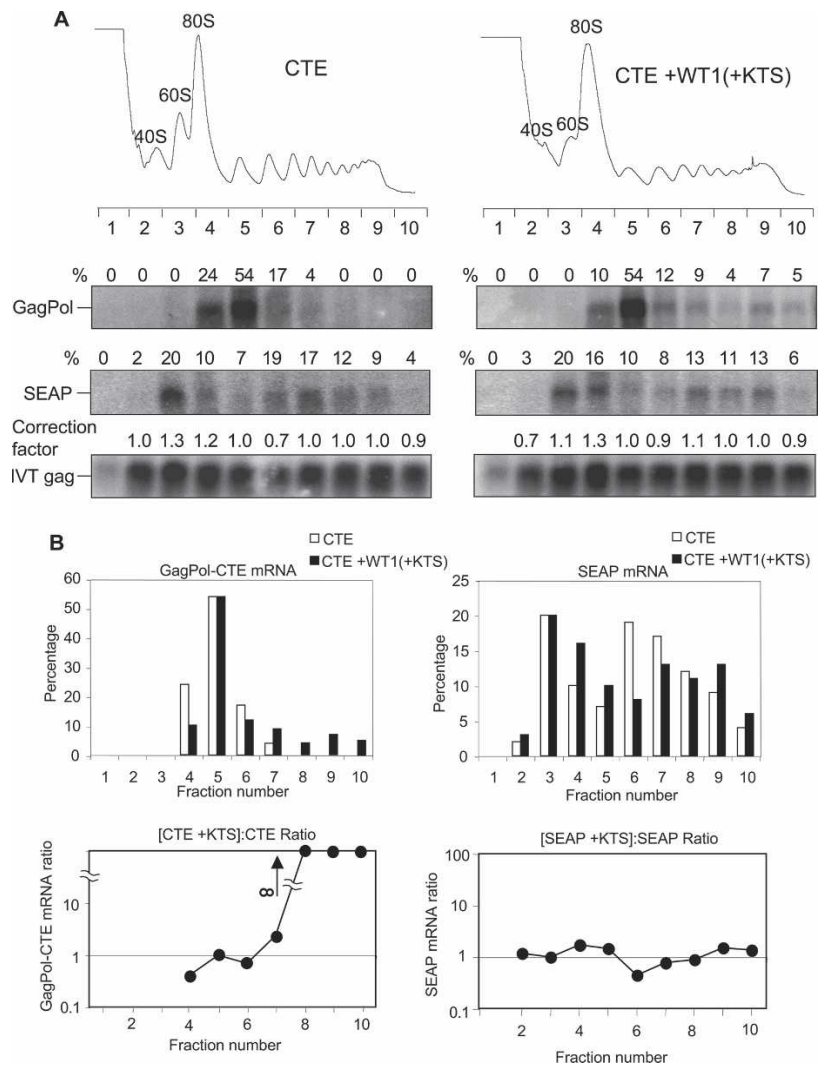

Figure 5. Polyribosome profile analysis of GagPol-CTE mRNA in transfected $293 \mathrm{~T}$ cells by sucrose gradient centrifugation. $(A)$ 293T Cells $\left(8 \times 10^{6}\right)$ were transfected with $15 \mu \mathrm{g}$ of pCMVGagPol-CTE in the absence or presence of $15 \mu \mathrm{g}$ of WT1 $(+\mathrm{KTS})$ plasmid. Forty-eight hours post-transfection, cells were harvested and cytoplasmic extracts were subjected to sucrose gradient centrifugation as described in Materials and Methods. The gradients were fractionated and the OD 254 was measured using a continuous flow cell. An in vitro transcribed gag RNA (IVTgag) was then added into each fraction as a control for recovery of RNA before RNA was isolated from each fraction. The isolated RNA was then analyzed for GagPol-CTE, SEAP mRNA, and IVTgag RNA using Northern blots. PhosphorImager analysis of the blot was used to quantitate the intensity of the bands. The measured intensity of each GagPol-CTE and SEAP band was then corrected for recovery, using the IVTgag RNA band in each fraction. The values shown for each fraction are the percentage of total GagPol-CTE or SEAP mRNA that was detected in that fraction. (B) The graphs show the distribution of GagPolCTE (left) and SEAP mRNA (right) in the CTE (white bars) and CTE + WT1 $1+$ KTS) gradients (black bars).

the right panels of Figure 5A show that the addition of WT1(+KTS) caused the redistribution of a significant amount of the GagPol-CTE RNA to heavier polyribosomes. In contrast, the distribution of the SEAP mRNA remained largely unchanged. Figure 5B directly compares the distribution of CTE or SEAP RNA with or without WT1(+KTS) expression. Together, these results demonstrate that expression of WT1(+KTS) promotes polyribosomal association and translation of the GagPolRNA containing the CTE, in addition to its slight effect on mRNA levels. In contrast, WT1(-KTS) had little ef- 
fect on the polyribosomal association of GagPol-RNA, consistent with its lack of an effect on the rate of Gag protein synthesis (see Supplementary Fig. S2).

WT1(+KTS) associates with polyribosomes in 293 cells

A recent paper showed that both the WT1 $(+\mathrm{KTS})$ and WT1(-KTS) proteins shuttle between the nucleus and the cytoplasm in several different cell types. It was also reported that both WT1 isoforms associate with translating polyribosomes in transfected COS-7 cells (Niksic et al. 2004).

To investigate whether the WT1(+KTS) protein associated with polyribosomes in $293 \mathrm{~T}$ cells, we transfected cells with pCMVGagPol-CTE and plasmids expressing T7-tagged WT1(+KTS) and made cytoplasmic extracts. The extracts were subjected to sucrose gradient centrifugation, and each fraction was analyzed on a Western blot using an anti-T7 antibody. We also performed a similar analysis on fractions from gradients run with extracts treated with $15 \mathrm{mM}$ EDTA to specifically disrupt the polyribosomes prior to centrifugation.

The Western blot analysis shown in Figure 6A demonstrated that WT1 $1+\mathrm{KTS})$ can be found throughout the gradient, including the polyribosomal fractions. This is consistent with the previous results reported in the COS-7 cells. The EDTA treatment (Fig. 6B) collapsed the polyribosomes (cf. the profiles of untreated and treated extracts) and shifted all of the WT1 protein to the fractions containing the ribosomal subunits. This strongly

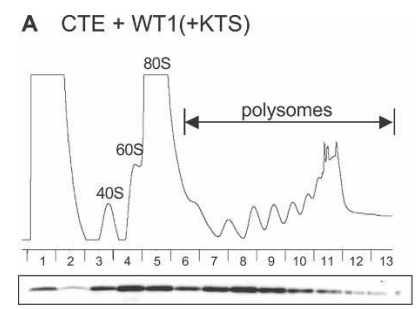

B CTE + WT1 $(+K T S)+$ EDTA

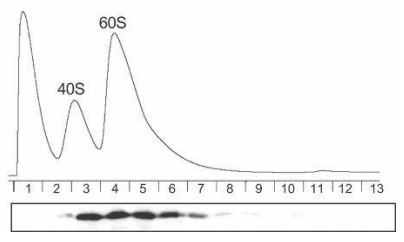

Figure 6. WT1 $(+\mathrm{KTS})$ is associated with polyribosomes in transfected $293 \mathrm{~T}$ cells. (A) Cells $\left(8 \times 10^{6}\right)$ were cotransfected with $15 \mu \mathrm{g}$ of pCMVGagPol-CTE, $2.5 \mu \mathrm{g}$ of pCMVSEAP, and 15 $\mu \mathrm{g}$ of WT1(+KTS) plasmids and were subjected to polyribosome analysis as described in Materials and Methods. The gradient was fractionated and the OD 254 of each fraction was measured. Proteins from each fraction were resolved by SDS-PAGE and analyzed by Western blotting using the anti-T7 antibody and

${ }^{125}$ I-Protein A. Optical density profiles of the gradient fractions are shown at the top. (B) The experiment was performed as in $A$, except that $15 \mathrm{mM}$ EDTA was added to the lysate before loading onto sucrose gradients containing 15 mM EDTA. suggests that the WT1 $(+\mathrm{KTS})$ protein is associated with true polyribosomal complexes and that it may specifically associate with the ribosomal subunits.

\section{Discussion}

The role of the WT1(-KTS) protein as an important transcription factor is well established. However, although a transcriptional role for a chimeric Ewing's Sarcoma gene (EWS)-WT1(+KTS) protein has been described (Reynolds et al. 2003), no clear function has been attributed to the native WT1(+KTS) protein, in spite of the fact that proper $+\mathrm{KTS} /-\mathrm{KTS}$ ratios are crucial in the development of several organs (Hammes et al. 2001; Davies et al. 2004; Wagner et al. 2005). In this study, we have shown for the first time that WT1(+KTS) functions at the post-transcriptional level to regulate RNA expression and, specifically, that the + KTS protein can function in conjunction with a cis-acting CTE to promote translation of an unspliced RNA with a retained intron.

WT1(+KTS) has previously been proposed to be involved in post-transcriptional regulation because of the apparent preferential association of + KTS isoforms with nuclear speckles and splicing factors (Larsson et al. 1995; Ladomery et al. 1999, 2003). This suggests that WT1(+KTS) might initially interact with the CTE-containing RNA in conjunction with the splicing machinery. Although the MPMV CTE functions specifically at the post-transcriptional level to enable the export and translation of unspliced or incompletely spliced RNA, the CTE does not divert the RNA from the splicing machinery, but enables the RNA to circumvent a cellular restriction that appears to require intron removal before export (Legrain et al. 1988; Chang and Sharp 1989; Hammarskjöld 1997). In fact, it has been well documented that RNAs that serve as substrates for CTE-mediated export initially interact with the splicing machinery even when they remain completely unspliced (Lu et al. 1990; Hammarskjöld 1997). It has also been shown that U2AF65 can stimulate the nuclear export and expression of an unspliced reporter RNA retaining an intron and that exogenously expressed U2AF65 can recruit Tap to mRNP complexes (Zolotukhin et al. 2002). These results thus suggest a role for splicing factors in the formation of an export-competent CTE-containing mRNP complex. Since WT1 $(+\mathrm{KTS})$ has been demonstrated to bind directly to U2AF65 (Davies et al. 1998), it will be of clear interest to determine whether this interaction plays a role in the ability of $\mathrm{WT} 1(+\mathrm{KTS})$ to enhance CTE function.

The KTS insertion in WT1 protein is extremely well conserved. However, our results demonstrate that a protein with a substitution of AAA for the KTS sequence functions as well as the original WT1 $(+\mathrm{KTS})$ protein, supporting the notion that the sole function of the insertion is to disrupt the linker between the third and fourth zinc finger and thus the structure of the protein. It also supports the previously proposed idea that the conservation of the specific KTS sequence might be due to a conservation necessary at the RNA level for proper splic- 
ing and maintenance of the ratios between the two isoforms (Davies et al. 2000).

In contrast to the functional importance of the KTS insertion, previous studies examining the function of WT1 have not demonstrated a clear role for the mammalian-specific alternative exon 5 , which includes or excludes 17 amino acids in the protein. Also, adult mice lacking this exon are viable and fertile (Natoli et al. 2002). This exon is evidently dispensable for at least some of the post-transcriptional effects of WT1 $1+\mathrm{KTS})$, since a protein lacking this exon was fully functional in our system.

Although WT1(+KTS) clearly enhanced polyribosome association of CTE-containing RNA, this protein also slightly increased the overall levels of this RNA relative to the SEAP mRNA that was transcribed from the same promoter. This suggests that WT1 $(+\mathrm{KTS})$ might also directly affect some aspect of RNA metabolism. Effects of WT1(+KTS) at multiple levels would not be surprising, since many recent studies have highlighted links between different steps in RNA processing (for a recent review, see Huang and Steitz 2005). In addition, Sam68, which also functions to promote translation of CTE-containing RNA (Coyle et al. 2003), has been reported to also effect alternative splicing, RNA stability, and polyadenylation (Matter et al. 2002; McLaren et al. 2004).

Our experiments demonstrate that WT1(+KTS) can function to promote expression from an RNA with a retained intron. Although expression from unspliced and incompletely spliced RNA is commonly observed in viruses, and intron retention seems to be a common form of alternative splicing in plants (Ner-Gaon et al. 2004), this form of alternative splicing seems to be relatively rare in higher organisms. In fact, there are only a few verified reports of protein expression from mammalian mRNAs with retained introns. One clearly documented example involves some of the members of the Id family of helix-loop-helix (HLH) transcription factors. Specifically, retention of the single small intron in the Id3 gene after vascular injury results in expression of an alternative protein isoform, which appears to function as a modulator of the protein expressed from the spliced RNA (Matsumura et al. 2001; Forrest et al. 2004). This may be particularly relevant, since a recent study demonstrated that deletion of the WT1 $1+\mathrm{KTS})$ isoform affected the expression of MASH1, an HLH transcription factor required for early neurogenesis (Wagner et al. 2005). However, no effects on MASH1 transcription were observed, leading Wagner et al. (2005) to hypothesize a post-transcriptional effect. Since the MASH1 gene, like the $I d$ genes, contains a single small intron, it will be of interest to determine whether the effects of the $+\mathrm{KTS}$ protein on MASH1 expression are related to intron retention.

WT1(-KTS), the "transcription factor" isoform of WT1, was shown to slightly increase RNA levels and protein expression from the CTE-containing RNA in the absence of WT1 $(+\mathrm{KTS})$. In contrast, expression of WT1(-KTS) clearly inhibited WT1(+KTS) enhancement of CTE function. This might be due to the previously demonstrated ability of the WT1 proteins to form heterodimers through their $\mathrm{N}$-terminal domains (Englert et al. 1995; Moffett et al. 1995; Reddy et al. 1995; Bruening et al. 1996). In support of this hypothesis, preliminary experiments suggest that while $\mathrm{N}$-terminal deletion mutants of WT1 $1+$ KTS $)$ can still enhance CTE function, expression is no longer inhibited by the WT1(-KTS) protein (Y.-c. Bor, D. Rekosh, and M.L. Hammarskjöld, unpubl.). Consistent with this finding, coexpression of WT1(-KTS) in excess over WT1(+KTS) in Xenopus oocytes abrogated the localization of WT1(+KTS) in B-snurposomes, but only if the $\mathrm{N}$ terminus was present (Ladomery et al. 2003).

WT1(+KTS) associates with polyribosomes in transfected $293 \mathrm{~T}$ cells, consistent with its ability to enhance mRNA translation. An association of this isoform with polyribosomes was also recently reported in monkey COS cells (Niksic et al. 2004). However, Niksic et al. (2004) also found that the WT1(-KTS) isoform associated with polyribosomes. This raises a conundrum, since our data clearly demonstrate that only the WT1(+KTS) isoform enhances GagPol expression from a CTE-containing mRNA. Further experiments are necessary to address the potential role of the WT1(-KTS) protein in translational regulation. It may be that WT1(-KTS) has a different set of targets than WT1 $1+\mathrm{KTS})$ or that it functions as a translational repressor. In our experiments, the $+\mathrm{KTS}$ protein was found in fractions containing the ribosomal subunits after treatment with 15 mM EDTA, suggesting that WT1 might associate directly with ribosomal proteins during translation. Alternatively, the protein could simply be associated with mRNP complexes that sediment in these fractions when the polyribosomes are disrupted.

The fact that WT1(-KTS), a protein that has been shown to act as a transcriptional regulator, functions as an inhibitor of post-transcriptional effects of WT1 $(+\mathrm{KTS})$ suggests the intriguing possibility that alternative splicing of WT1 might serve to coordinate regulation of transcriptional and post-transcriptional events. One possibility is that genes that are regulated by WT1(-KTS) at the transcriptional level are also regulated post-transcriptionally by WT1 $(+\mathrm{KTS})$. Another possibility is that the two proteins serve to coordinately regulate expression of different genes at the transcriptional and post-transcriptional level. Elucidation of this will require the definitive identification of gene targets for WT1 $1+\mathrm{KTS})$. While the 5A1 sequence is clearly functioning as a cellular CTE and was identified in coimmunoprecipitations with $\mathrm{WT} 1(+\mathrm{KTS})$, the physiological relevance of this remains unclear, since a coding mRNA containing this sequence has not been reported. More interesting is the fact that WT1(+KTS) also enhanced expression mediated by the recently discovered CTE in ACTN4. As mentioned above, the closely related ACTN1 has been identified (Morrison et al. 2006) as a potential WT1 target using a three-hybrid system. These results, coupled with the established role of ACTN4 in kidney function, suggest that $\mathrm{WT} 1(+\mathrm{KTS})$ in conjunction with CTEs may regulate nonmuscle $\alpha$-actinins in kidney cells. 
The last several years have provided increasing evidence for the importance of gene regulation at the posttranscriptional level, especially in mammalian systems. The genome project has revealed that much of the complexity of higher organisms is not due to more genes, but to alternative splicing and other events at the post-transcriptional level. Keene and Tenenbaum (2002) originally proposed that untranslated sequence elements for regulation (USERcodes) in mammalian mRNA could provide the signals for post-transcriptional operons, enabling the coordinated expression of certain subsets of mRNAs in response to signals during development and differentiation. The fact that both WT1 $(+\mathrm{KTS})$ and Sam68, RNA-binding proteins believed to play important but distinct roles in development and differentiation, can both interact with CTE-containing RNAs to enhance expression at the post-transcriptional level gives further credence to the validity of this hypothesis.

\section{Materials and methods}

\section{Plasmids, cell lines, and transient transfections}

Many of the plasmids used in this study have been previously described (Jin et al. 2003). Plasmids expressing full-length mouse WT1(+exon 5 and +KTS; pHR3056), WT1(+exon 5 and -KTS; pHR3057), WT1(-exon 5 and +KTS; pHR3101), and EGR1 (pHR3062) have also been described previously (Ladomery et al. 1999). The WT1(+AAA) plasmid (pHR3100), in which the sequence encoding the KTS motif was mutated to encode AAA, was made by performing a QuikChange mutagenesis according to the manufacturer's recommendation (Stratagene). The desired mutations were confirmed by sequencing. All expressed WT1 proteins contain a $\mathrm{T} 7$ tag at the $\mathrm{N}$ terminus.

293T/17 cells were maintained and transfected, and supernatants from transfected cells were collected at the indicated times post-transfection and subjected to $\mathrm{p} 24$ and SEAP analysis as previously described (Jin et al. 2003).

\section{RNA fractionation and Northern blot analysis}

The methods used for total and cytoplasmic RNA extraction, poly(A) mRNA selection, and Northern blot analysis were previously described (Jin et al. 2003), except that the positively charged nylon membrane BrightStar-Plus (Ambion, Inc.) was used instead of NitroPlus 2000 (Osmonics) in some experiments. $293 \mathrm{~T}$ cells were harvested at $65 \mathrm{~h}$ post-transfection. A SacI-BglII fragment (nucleotides 682-2093) of the HIV-1 BH10 clone and BamHI fragment of the human SEAP cDNA (nucleotides 213-1698) were labeled with $\left[\alpha-{ }^{32} \mathrm{P}\right] \mathrm{dCTP}$ by using the Rediprime II Kit (GE Healthcare, Amersham Biosciences). Northern blots were quantitated with a Molecular Dynamics PhosphorImager and ImageQuant analysis software.

\section{${ }^{35}$ S labeling and immunoprecipitations}

Transfected 293T cells were washed twice with methionine and cysteine-free Dulbecco's modified Eagle medium (Gibco/Invitrogen) and then incubated for $20 \mathrm{~min}$ at $37^{\circ} \mathrm{C}$ in labeling medium containing $200 \mu \mathrm{Ci}$ of ${ }^{35} \mathrm{~S}$-translabel (ICN) and $10 \%$ dialyzed bovine calf serum. "Chase" experiments and immunoprecipitations were performed as previously described (Jin et al. 2003).

\section{Polyribosome analysis}

The polyribosome analysis was performed essentially as previously described (Jin et al. 2003), except that for the RNA experiments, transfected cells were split $1 / 3$ at $24 \mathrm{~h}$ post-transfection. At $48 \mathrm{~h}$ post-transfection, the cells were exposed to $50 \mu \mathrm{g} / \mathrm{mL}$ cycloheximide for $30 \mathrm{~min}$ at $37^{\circ} \mathrm{C}$. Cells were washed twice with cold PBS containing $50 \mu \mathrm{g} / \mathrm{mL}$ cycloheximide and harvested by scraping. After a brief centrifugation, cell pellets were resuspended in $0.25 \mathrm{~mL}$ of cold RSB buffer $(10 \mathrm{mM}$ Tris- $\mathrm{HCl}$ at $\mathrm{pH} 7.4,10 \mathrm{mM} \mathrm{NaCl}, 3 \mathrm{mM} \mathrm{MgCl}{ }_{2}$ ) containing $250 \mathrm{U}$ of RNasin (Promega), and an additional $0.25 \mathrm{~mL}$ of RSB containing $1 \%$ Triton X-100, 1\% deoxycholate, and 2\% Tween 20 was then added to lyse the cells. After sucrose gradient centrifugation, 10 ng of a 267-nt-long fragment of in vitro transcribed gag RNA was added to each fraction as a control for recovery. The fractions were then incubated with $0.2 \mathrm{mg} / \mathrm{mL}$ of Proteinase $\mathrm{K}$ in the presence of $0.5 \%$ SDS for $30 \mathrm{~min}$ at $42^{\circ} \mathrm{C}$ and extracted twice with an equal volume of phenol/chloroform/isoamyl alcohol (25:24:1) and once with chloroform/isoamyl alcohol (49:1). RNA from each sample was precipitated by the addition of $30 \mu \mathrm{L}$ of $3 \mathrm{M}$ sodium acetate $(\mathrm{pH} 5.2)$ and $825 \mu \mathrm{L}$ of $100 \%$ ethanol, and was collected by centrifugation. The RNA pellets were washed with $75 \%$ ethanol and resuspended in $4 \mu \mathrm{L}$ of water with $15.5 \mu \mathrm{L}$ of RS buffer $(2 \mu \mathrm{L}$ of $10 \times$ MOPS, $3.5 \mu \mathrm{L}$ of $37 \%$ formaldehyde, $10 \mu \mathrm{L}$ of formamide). Samples were incubated for $10 \mathrm{~min}$ at $55^{\circ} \mathrm{C}$, cooled on ice, and loaded onto a $1 \%$ agarose gel containing formaldehyde.

\section{Western blot analysis and antibodies}

The Western blot analysis was performed as previously described (Hammarskjöld et al. 1986). In brief, lysates from transfected cell were separated in a $15 \%$ SDS-PAGE and transferred to an Immobilon-P membrane (Millipore). For detection of T7tagged WT1 proteins, blots were probed with a 1:5000 dilution of mouse anti-T7 monoclonal antibody (Novagen). Blots were normally developed using a horseradish peroxidase-coupled second antibody and the enhanced chemiluminescence system (Amersham Biosciences).

\section{Acknowledgments}

We thank Joy Morgenegg for expert tissue culture assistance and Alex Ward for comments on the manuscript. This work was supported by National Institutes of Health grants AI 34271 and AI 054335 to M.-L.H., AI 47008 to D.R., and Association for International Cancer Research, Scotland, UK, grant number 02025 to M.R.L. Salary support for M.L.H and D.R. was provided by the Charles H. Ross Jr. and Myles H. Thaler Endowments at the University of Virginia.

\section{References}

Barbaux, S., Niaudet, P., Gubler, M.C., Grunfeld, J.P., Jaubert, F., Kuttenn, F., Fekete, C.N., Souleyreau-Therville, N., Thibaud, E., Fellous, M., et al. 1997. Donor splice-site mutations in WT1 are responsible for Frasier syndrome. Nat. Genet. 17: 467-470.

Bardeesy, N. and Pelletier, J. 1998. Overlapping RNA and DNA binding domains of the wt1 tumor suppressor gene product. Nucleic Acids Res. 26: 1784-1792.

Bickmore, W.A., Oghene, K., Little, M.H., Seawright, A., van Heyningen, V., and Hastie, N.D. 1992. Modulation of DNA binding specificity by alternative splicing of the Wilms tu- 
mor wt1 gene transcript. Science 257: 235-237.

Braun, I.C., Herold, A., Rode, M., Conti, E., and Izaurralde, E. 2001. Overexpression of TAP/p15 heterodimers bypasses nuclear retention and stimulates nuclear mRNA export. $J$. Biol. Chem. 276: 20536-20543.

Bray, M., Prasad, S., Dubay, J.W., Hunter, E., Jeang, K.T., Rekosh, D., and Hammarskjöld, M.L. 1994. A small element from the Mason-Pfizer monkey virus genome makes human immunodeficiency virus type 1 expression and replication Rev- independent. Proc. Natl. Acad. Sci. 91: 1256-1260.

Bruening, W., Moffett, P., Chia, S., Heinrich, G., and Pelletier, J. 1996. Identification of nuclear localization signals within the zinc fingers of the WT1 tumor suppressor gene product. FEBS Lett. 393: 41-47.

Call, K.M., Glaser, T., Ito, C.Y., Buckler, A.J., Pelletier, J., Haber, D.A., Rose, E.A., Kral, A., Yeger, H., Lewis, W.H., et al. 1990. Isolation and characterization of a zinc finger polypeptide gene at the human chromosome 11 Wilms' tumor locus. Cell 60: 509-520.

Caricasole, A., Duarte, A., Larsson, S.H., Hastie, N.D., Little, M., Holmes, G., Todorov, I., and Ward, A. 1996. RNA binding by the Wilms tumor suppressor zinc finger proteins. Proc. Natl. Acad. Sci. 93: 7562-7566.

Chang, D.D. and Sharp, P.A. 1989. Regulation by HIV Rev depends upon recognition of splice sites. Cell 59: 789-795.

Coyle, J.H., Guzik, B.W., Bor, Y.C., Jin, L., Eisner-Smerage, L., Taylor, S.J., Rekosh, D., and Hammarskjöld, M.L. 2003. Sam68 enhances the cytoplasmic utilization of intron-containing RNA and is functionally regulated by the nuclear kinase Sik/BRK. Mol. Cell. Biol. 23: 92-103.

Dallosso, A.R., Hancock, A.L., Brown, K.W., Williams, A.C., Jackson, S., and Malik, K. 2004. Genomic imprinting at the WT1 gene involves a novel coding transcript (AWT1) that shows deregulation in Wilms' tumours. Hum. Mol. Genet. 13: 405-415.

Davies, R.C., Calvio, C., Bratt, E., Larsson, S.H., Lamond, A.I., and Hastie, N.D. 1998. WT1 interacts with the splicing factor U2AF65 in an isoform-dependent manner and can be incorporated into spliceosomes. Genes \& Dev. 12: $3217-$ 3225.

Davies, R.C., Bratt, E., and Hastie, N.D. 2000. Did nucleotides or amino acids drive evolutionary conservation of the WT1 +/-KTS alternative splice? Hum. Mol. Genet. 9: 1177-1183.

Davies, J.A., Ladomery, M., Hohenstein, P., Michael, L., Shafe, A., Spraggon, L., and Hastie, N. 2004. Development of an siRNA-based method for repressing specific genes in renal organ culture and its use to show that the Wt1 tumour suppressor is required for nephron differentiation. Hum. Mol. Genet. 13: 235-246.

Discenza, M.T., Vaz, D., Hassell, J.A., and Pelletier, J. 2004. Activation of the WT1 tumor suppressor gene promoter by Pea3. FEBS Lett. 560: 183-191.

Englert, C., Vidal, M., Maheswaran, S., Ge, Y., Ezzell, R.M., Isselbacher, K.J., and Haber, D.A. 1995. Truncated WT1 mutants alter the subnuclear localization of the wild-type protein. Proc. Natl. Acad. Sci. 92: 11960-11964.

Ernst, R., Bray, M., Rekosh, D., and Hammarskjöld, M.-L. 1997. A structured retroviral RNA element that mediates nucleocytoplasmic export of intron-containing RNA. Mol. Cell. Biol. 17: 135-144.

Forrest, S.T., Barringhaus, K.G., Perlegas, D., Hammarskjöld, M.L., and McNamara, C.A. 2004. Intron retention generates a novel Id3 isoform that inhibits vascular lesion formation. J. Biol. Chem. 279: 32897-32903.

Fribourg, S., Braun, I.C., Izaurralde, E., and Conti, E. 2001. Structural basis for the recognition of a nucleoporin FG repeat by the NTF2-like domain of the TAP/p15 mRNA nuclear export factor. Mol. Cell 8: 645-656.

Galante, P.A., Sakabe, N.J., Kirschbaum-Slager, N., and de Souza, S.J. 2004. Detection and evaluation of intron retention events in the human transcriptome. RNA 10: 757-765.

Gessler, M., Poustka, A., Cavenee, W., Neve, R.L., Orkin, S.H., and Bruns, G.A. 1990. Homozygous deletion in Wilms tumours of a zinc-finger gene identified by chromosome jumping. Nature 343: 774-778.

Gessler, M., Konig, A., and Bruns, G.A. 1992. The genomic organization and expression of the WT1 gene. Genomics 12: 807-813.

Gruter, P., Tabernero, C., von Kobbe, C., Schmitt, C., Saavedra, C., Bachi, A., Wilm, M., Felber, B.K., and Izaurralde, E. 1998. TAP, the human homolog of Mex67p, mediates CTE-dependent RNA export from the nucleus. Mol. Cell 1: 649-659.

Guzik, B.W., Levesque, L., Prasad, S., Bor, Y.C., Black, B.E., Paschal, B.M., Rekosh, D., and Hammarskjöld, M.L. 2001. NXT1 (p15) is a crucial cellular cofactor in TAP-dependent export of intron-containing RNA in mammalian cells. Mol. Cell. Biol. 21: 2545-2554.

Haber, D.A., Sohn, R.L., Buckler, A.J., Pelletier, J., Call, K.M., and Housman, D.E. 1991. Alternative splicing and genomic structure of the Wilms tumor gene WT1. Proc. Natl. Acad. Sci. 88: 9618-9622.

Hammarskjöld, M.L. 1997. Regulation of retroviral RNA export. Semin. Cell Dev. Biol. 8: 83-90.

- 2001. Constitutive transport element-mediated nuclear export. Curr. Top. Microbiol. Immunol. 259: 77-93.

Hammarskjöld, M.L., Wang, S.-C., and Klein, G. 1986. Highlevel expression of the Epstein-Barr virus EBNA1 protein in CV1 cells and human lymphoid cells using a SV40 late replacement vector. Gene 43: 41-50.

Hammes, A., Guo, J.K., Lutsch, G., Leheste, J.R., Landrock, D., Ziegler, U., Gubler, M.C., and Schedl, A. 2001. Two splice variants of the Wilms' tumor 1 gene have distinct functions during sex determination and nephron formation. Cell 106: 319-329.

Huang, Y. and Steitz, J.A. 2005. SRprises along a messenger's journey. Mol. Cell 17: 613-615.

Izaurralde, E. 2002. Nuclear export of messenger RNA. Results Probl. Cell Differ. 35: 133-150.

Jin, L., Guzik, B.W., Bor, Y.C., Rekosh, D., and Hammarskjöld, M.L. 2003. Tap and NXT promote translation of unspliced mRNA. Genes \& Dev. 17: 3075-3086.

Kaplan, J.M., Kim, S.H., North, K.N., Rennke, H., Correia, L.A., Tong, H.Q., Mathis, B.J., Rodriguez-Perez, J.C., Allen, P.G., Beggs, A.H., et al. 2000. Mutations in ACTN4, encoding $\alpha$-actinin-4, cause familial focal segmental glomerulosclerosis. Nat. Genet. 24: 251-256.

Katahira, J., Strasser, K., Podtelejnikov, A., Mann, M., Jung, J.U., and Hurt, E. 1999. The Mex67p-mediated nuclear mRNA export pathway is conserved from yeast to human. EMBO $\mathrm{J}$. 18: 2593-2609.

Keene, J.D. and Tenenbaum, S.A. 2002. Eukaryotic mRNPs may represent posttranscriptional operons. Mol. Cell 9: 11611167.

Kent, J., Coriat, A.M., Sharpe, P.T., Hastie, N.D., and van Heyningen, V. 1995. The evolution of WT1 sequence and expression pattern in the vertebrates. Oncogene 11: 1781-1792.

Klamt, B., Koziell, A., Poulat, F., Wieacker, P., Scambler, P., Berta, P., and Gessler, M. 1998. Frasier syndrome is caused by defective alternative splicing of WT1 leading to an altered ratio of WT1 +/-KTS splice isoforms. Hum. Mol. Genet. 7: 709-714.

Ladomery, M.R., Slight, J., Mc Ghee, S., and Hastie, N.D. 1999. 
Presence of WT1, the Wilm's tumor suppressor gene product, in nuclear poly(A)+ ribonucleoprotein. I. Biol. Chem. 274: 36520-36526.

Ladomery, M., Sommerville, J., Woolner, S., Slight, J., and Hastie, N. 2003. Expression in Xenopus oocytes shows that WT1 binds transcripts in vivo, with a central role for zinc finger one. J. Cell Sci. 116: 1539-1549.

Laity, J.H., Dyson, H.J., and Wright, P.E. 2000. Molecular basis for modulation of biological function by alternate splicing of the Wilms' tumor suppressor protein. Proc. Natl. Acad. Sci. 97: 11932-11935.

Larsson, S.H., Charlieu, J.P., Miyagawa, K., Engelkamp, D., Rassoulzadegan, M., Ross, A., Cuzin, F., van Heyningen, V., and Hastie, N.D. 1995. Subnuclear localization of WT1 in splicing or transcription factor domains is regulated by alternative splicing. Cell 81: 391-401.

Lee, T.H. and Pelletier, J. 2001. Functional characterization of WT1 binding sites within the human vitamin D receptor gene promoter. Physiol. Genomics 7: 187-200.

Legrain, P., Seraphin, B., and Rosbash, M. 1988. Early commitment of yeast pre-mRNA to the spliceosome pathway. Mol. Cell. Biol. 8: 3755-3760.

Lu, X.B., Heimer, J., Rekosh, D., and Hammarskjöld, M.L. 1990. U1 small nuclear RNA plays a direct role in the formation of a rev-regulated human immunodeficiency virus env mRNA that remains unspliced. Proc. Natl. Acad. Sci. 87: 75987602.

Matsumura, M.E., Li, F., Berthoux, L., Wei, B., Lobe, D.R., Jeon, C., Hammarskjöld, M.L., and McNamara, C.A. 2001. Vascular injury induces posttranscriptional regulation of the Id3 gene: Cloning of a novel Id3 isoform expressed during vascular lesion formation in rat and human atherosclerosis. Arterioscler. Thromb. Vasc. Biol. 21: 752-758.

Matter, N., Herrlich, P., and Konig, H. 2002. Signal-dependent regulation of splicing via phosphorylation of Sam68. Nature 420: 691-695.

McLaren, M., Asai, K., and Cochrane, A. 2004. A novel function for Sam68: Enhancement of HIV-1 RNA 3' end processing. RNA 10: 1119-1129.

Moffett, P., Bruening, W., Nakagama, H., Bardeesy, N., Housman, D., Housman, D.E., and Pelletier, J. 1995. Antagonism of WT1 activity by protein self-association. Proc. Natl. Acad. Sci. 92: 11105-11109.

Morrison, A., Venables, J., Dellaire, G., and Ladomery, M. 2006. The Wilms' tumour suppressor protein WT1 (+KTS isoform) binds $\alpha$-actin- 1 mRNA via its zinc-finger domain. Biochem. Cell Biol. (in press).

Natoli, T.A., McDonald, A., Alberta, J.A., Taglienti, M.E., Housman, D.E., and Kreidberg, J.A. 2002. A mammal-specific exon of WT1 is not required for development or fertility. Mol. Cell. Biol. 22: 4433-4438.

Ner-Gaon, H., Halachmi, R., Savaldi-Goldstein, S., Rubin, E., Ophir, R., and Fluhr, R. 2004. Intron retention is a major phenomenon in alternative splicing in Arabidopsis. Plant $\mathrm{T}$. 39: 877-885

Niksic, M., Slight, J., Sanford, J.R., Caceres, J.F., and Hastie, N.D. 2004. The Wilms' tumour protein (WT1) shuttles between nucleus and cytoplasm and is present in functional polysomes. Hum. Mol. Genet. 13: 463-471.

Ortega, A., Niksic, M., Bachi, A., Wilm, M., Sanchez, L., Hastie, N., and Valcarcel, J. 2003. Biochemical function of femalelethal (2)D/Wilms' tumor suppressor-1-associated proteins in alternative pre-mRNA splicing. J. Biol. Chem. 278: 30403047.

Pollard, V.W. and Malim, M.H. 1998. The HIV-1 Rev protein. Annu. Rev. Microbiol. 52: 491-532.
Rae, F.K., Martinez, G., Gillinder, K.R., Smith, A., Shooter, G., Forrest, A.R., Grimmond, S.M., and Little, M.H. 2004. Analysis of complementary expression profiles following WT1 induction versus repression reveals the cholesterol/ fatty acid synthetic pathways as a possible major target of WT1. Oncogene 23: 3067-3079.

Rauscher III, F.J. 1993. The WT1 Wilms tumor gene product: A developmentally regulated transcription factor in the kidney that functions as a tumor suppressor. FASEB J. 7: 896-903.

Rauscher III, F.J., Morris, J.F., Tournay, O.E., Cook, D.M., and Curran, T. 1990. Binding of the Wilms' tumor locus zinc finger protein to the EGR-1 consensus sequence. Science 250: 1259-1262.

Reddy, J.C., Morris, J.C., Wang, J., English, M.A., Haber, D.A., Shi, Y., and Licht, J.D. 1995. WT1-mediated transcriptional activation is inhibited by dominant negative mutant proteins. J. Biol. Chem. 270: 10878-10884.

Reynolds, P.A., Smolen, G.A., Palmer, R.E., Sgroi, D., Yajnik, V., Gerald, W.L., and Haber, D.A. 2003. Identification of a DNA-binding site and transcriptional target for the EWSWT1(+KTS) oncoprotein. Genes \& Dev. 17: 2094-2107.

Rosenfeld, C., Cheever, M.A., and Gaiger, A. 2003. WT1 in acute leukemia, chronic myelogenous leukemia and myelodysplastic syndrome: Therapeutic potential of WT1 targeted therapies. Leukemia 17: 1301-1312.

Scharnhorst, V., van der Eb, A.J., and Jochemsen, A.G. 2001. WT1 proteins: Functions in growth and differentiation. Gene 273: 141-161.

Smith, A.J., Srinivasakumar, N., Hammarskjöld, M.L., and Rekosh, D. 1993. Requirements for incorporation of Prl60gagpol from human immunodeficiency virus type 1 into viruslike particles. J. Virol. 67: 2266-2275.

Srinivasakumar, N., Chazal, N., Helga-Maria, C., Prasad, S., Hammarskjöld, M.L., and Rekosh, D. 1997. The effect of viral regulatory protein expression on gene delivery by human immunodeficiency virus type 1 vectors produced in stable packaging cell lines. J. Virol. 71: 5841-5848.

Thäte, C., Englert, C., and Gessler, M. 1998. Analysis of WT1 target gene expression in stably transfected cell lines. Oncogene 17: 1287-1294.

Vajihala, P.R., Macmillan, E., Gonda, T., and Little, M. 2003. The Wilms' tumour suppressor protein, WT1, undergoes CRM1-independent nucleocytoplasmic shuttling. FEBS Lett. 554: 143-148.

Wagner, N., Wagner, K.D., Hammes, A., Kirschner, K.M., Vidal, V.P., Schedl, A., and Scholz, H. 2005. A splice variant of the Wilms' tumour suppressor Wt1 is required for normal development of the olfactory system. Development 132: 13271336.

Zhai, G., Iskandar, M., Barilla, K., and Romaniuk, P.J. 2001. Characterization of RNA aptamer binding by the Wilms' tumor suppressor protein WT1. Biochemistry 40: 20322040.

Zolotukhin, A.S., Tan, W., Bear, J., Smulevitch, S., and Felber, B.K. 2002. U2AF participates in the binding of TAP (NXF1) to mRNA. J. Biol. Chem. 277: 3935-3942. 


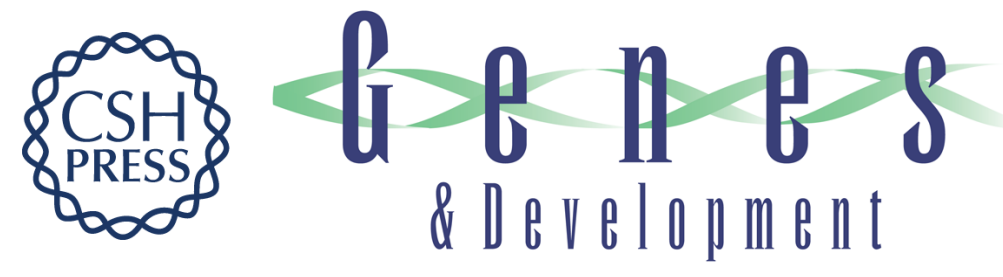

\section{The Wilms' tumor 1 (WT1) gene (+KTS isoform) functions with a CTE to enhance translation from an unspliced RNA with a retained intron}

Yeou Bor, Jennifer Swartz, Avril Morrison, et al.

Genes Dev. 2006, 20:

Access the most recent version at doi:10.1101/gad.1402306

\section{Supplemental http://genesdev.cshlp.org/content/suppl/2006/06/01/gad.1402306.DC1 Material}

References This article cites 67 articles, 31 of which can be accessed free at: http://genesdev.cshlp.org/content/20/12/1597.full.html\#ref-list-1

\section{License}

Email Alerting

Receive free email alerts when new articles cite this article - sign up in the box at the top Service

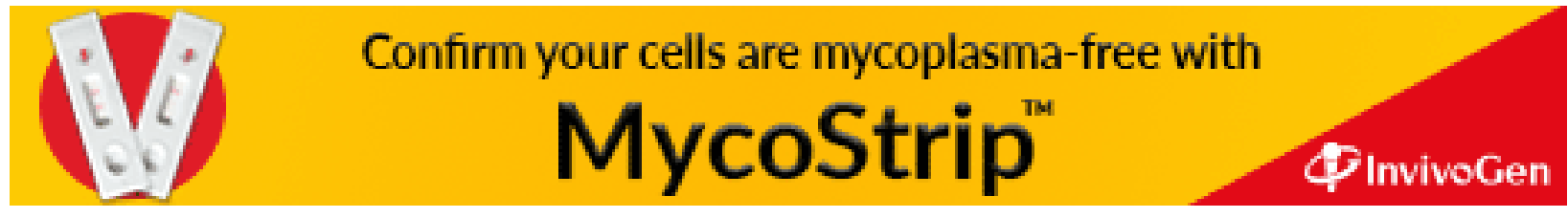

